\title{
Effects of Form-Focused Instruction in the Flipped Classroom Model on Non-English-Majored Graduates' English Writing
}

\author{
Yougen $\mathrm{Lou}^{1} \&$ Zejuan $\mathrm{Li}^{1}$ \\ ${ }^{1}$ School of Foreign Studies, Yangtze University, Jingzhou City, China \\ Correspondence: Zejuan Li, School of Foreign Studies, Yangtze University, Jingzhou City, China.
}

Received: March 23, 2018

Accepted: April 17, 2018

Online Published: April 25, 2018

doi:10.20849/aes.v3i2.373

URL: https://doi.org/10.20849/aes.v3i2.373

\begin{abstract}
This paper reviewed a one-term experiment made with a new writing teaching method, form-focused instruction(FFI), in the flipped classroom model) used in teaching English writing to 102 first-year non-English-majored graduate students from Yangtze University as participants. The participants in the control group, CG, were taught by the traditional English writing method: grammar-translation teaching method and the participants in the treatment group, TG, were taught by the new English writing teaching method of FFI. The results showed that 1) Compared with a traditional English writing approach for CG, FFI in the flipped classroom model used in teaching English writing for TG did a better job in enhancing students' English writing ability; 2) There were significant differences between males in CG and TG, and females in CG and TG; 3) Participates in TG held positive opinions towards FFI in the flipped classroom model in English writing.
\end{abstract}

Keywords: form-focused instruction, non-English-majored graduates, English writing, flipped classroom

\section{Introduction}

Every non-English-majored graduate is required to learn English academic writing. How to improve non-English-majored graduate students' ability in English academic writing is an important research program for English teachers in teaching non-English-majored graduates' English. New non-English-majored graduates' English academic writing methods are introduced to non-English-majored graduates' English teachers in their English academic writing teaching practice. Form-focused instruction is one of new non-English-majored graduates' English academic writing methods is introduced to non-English-majored graduates' English teachers to be utilized in their English academic writing teaching practice. Form-focused instruction has been popular in the world. Form-focused instruction (FFI) is an important role in task-based language teaching. FFI, focus on form instruction, was first used by Michael Long (Long, 1988). Long (Long, 1991) defined focus on form as 'overtly draws students' attention to linguistic elements as they arise incidentally in lessons whose overriding focus is on meaning or communication' (pp. 45-46). Focus on form was different from focus on forms. Focus on forms involves traditional language teaching consisting of the presentation and practice of items drawn from a structural syllabus (Ellis, 2016). Long and Ellis, their studies provided the solid foundation for us to further study form-focused instruction.

\section{Literature Review}

According to the theory of Constructivism, knowledge is not taught but is learned by the learner himself through constructing the new knowledge on the basis of old knowledge, under certain settings, with the help of others, such as the teachers or learning partners, utilizing certain study resources. So the student is the center of teaching and student-centered methodology should be used. That is to say, the student is the center of teaching and the teacher works as the organizer, facilitator and motivator, utilizing setting, cooperation and dialogue to motivate students' interests, activities and creative. Teachers should meet the students' needs. The flipped classroom model agrees with the theory of Constructivism.

Many researchers have been interested in FFI. Some researchers reported the implication of FFI in vocabulary (Beniko \& Krashen, 2004). The researcher (Amber, 2009) studied the application of FFI in grammatical level. In China, recent years, studies on FFI attracted more researchers' attention. The researchers studied effects of FFI on language learners' lexical growth (Huang, 2009 \& Wang, 2016). There were researchers' studies on effects of FFI on learners' oral ability (Gao, $2009 \& \mathrm{Li}, 2013)$ and on learners' lexical, grammatical, pronunciation ability 
via post-task interaction (Wang, 2016).

According to Bergmann \& Sams (Bergmann \& Sams, 2012), a flipped classroom can be described as a setting where that "which is traditionally done in class is now done at home, and that which is traditionally done as homework is now completed in class" (p. 13). The flipped classroom model changes the view of the classroom from being a knowledge station to being a place for student engagement and formative assessment of students' progress (Kang, 2015). Benefits to implementing the flipped classroom model include students learning at their own pace, reinforcing the teacher-student relationship (Bergmann \& Sams, 2012) and students benefitted from the use of technology in learning English (Aljumah, 2012 \& Al-Kathiri, 2015). On the other hand, there are some challenges with accompanying the implementation of the flipped classroom model such as students having difficulty adjusting to being active learners or neglecting to do the out-of-class work (Huelskamp, 2015). Another challenge is that teachers are not willing or capable of changing and adopting the use of technology (Educause Learning Initiativ, 2012).

There were few studies on effects of FFI in the flipped classroom model on non-English-majored graduates' English writing. This paper will focus on FFI in the flipped classroom model on non-English-majored graduates' English writing.

\section{Methodology and Data Collection}

\subsection{Research Design}

This study included two tests related to English writing to provide the information on non-English-majored graduate students' scores of English writing before and after trained by FFI in the flipped classroom mode and interviews on FFI in the flipped classroom mode applied in non-English-majored graduate students' English writing. The following research questions would be answered in this study:

1) As a result of implementing FFI in the flipped classroom mode, were there any significant differences between CG's and TG's improvement in English writing applied skills and ability?

2) Were there any significant differences between male non-English-majored graduate students and female non-English-majored graduate students in CG and TG?

3) Did participates in TG hold positive opinions towards FFI in the flipped classroom mode on non-English-majored graduate students' English writing?

\subsection{Participants}

In September, 2017, 102 first-year Non-English-majored graduate students (Chinese as their first or mother language) majored history, economics, agriculture, plant protection, floriculture and veterinary from Yangtze University were volunteers in this study. 102 first-year Non-English-majored graduate students, taught by the same male instructor during the whole academic term (September 12, 2017 to December 22, 2017), were 59 females and 43 males, their average age 23. All 102 participants had passed the College English Test (CET) 4, but had not passed CET 6. All 102 participants taught by the 43-year-old male English writing instructor were divided randomly into two groups: 51 participants as the Control Group (CG) with the traditional grammar-translation English writing teaching method and 51 participants as the Treatment Group (TG) with FFI in the flipped classroom model in English writing. Both $\mathrm{CG}$ and TG had the similar level of education background, family background, personality and life experiences, which was to say, their overall learning and cognitive abilities were almost equal. 
Table 1. The demographic features of the survey participants

\begin{tabular}{lcc}
\hline Variables & Number=102 & Percentage \\
\hline Age & & \\
21 & 11 & 10.78 \\
22 & 13 & 12.75 \\
23 & 40 & 39.22 \\
24 & 21 & 20.59. \\
25 & 17 & 16.66 \\
Gender & & \\
Female & 59 & 57.84 \\
Male & 43 & 42.16 \\
Majors & & \\
Agriculture & 19 & 18.63 \\
Plant protection & 18 & 17.65 \\
Floriculture & 17 & 16.65 \\
History & 15 & 14.71 \\
Economics & 15 & 14.71 \\
Veterinary & 18 & 17.65 \\
\hline
\end{tabular}

\subsection{Instruments}

The instruments adopted in this study were tests on English writing applied ability to CG and TG, and interviews with TG on FFI in the flipped classroom used in English writing.

\subsubsection{English Writing Applied Ability Pre-test}

All the 102 non-English-majored graduates were attended the English writing applied ability tests at 15:30-16:00 on September 12,2017 in one classroom to gain the first-year non-English-majored graduate students' scores on English writing applied ability in CG and TG before the experiment. All the 102 non-English-majored graduates were required to complete the English writing tests in 30minutes. The materials for English writing applied ability tests in this study were taken from the English writing part of June, 2016 national College English Test (CET) 6, total 710 points for CET6, 106 points for the English writing par of CET 6.

\subsubsection{English Writing Applied Ability Post-test}

All the 102 Non-English-majored graduates were attended the English writing applied skills and ability tests at 15:00-15:30 on December 22, 2017 in a classroom to gain the first-year non-English-majored graduate students' scores changes in English writing applied ability between CG and TG after the experiment. All the 102 non-English-majored graduates were required to complete the tests in 30 minutes. The materials for English writing applied ability tests in this study were taken from the writing part of December, 2016 national College English Test (CET) 6, total 710 points for CET6, 106 points for the English writing par of CET 6.

\subsubsection{Interviews}

After the experiment, all 51 participants in TG in this study were interviewed in one classroom to be required to write down their responses towards the following interview questions: 1) Do you think your English writing skills and ability has been improved by the new writing teaching method of FFI in the flipped classroom model in English writing? 2) What are difficulties (such as difficult to understand FFI, how to utilize FFI) when you apply FFI in the flipped classroom model in your English writing? 3) Do you think all of you in TG are benefited by the new writing teaching method of FFI in the flipped classroom model in your English writing?

\subsection{Data Collection and Analysis}

Two tests on English writing applied skills and ability before the experiment (September 12, 2017) and two tests on English writing applied skills and ability (December 22,2017) were conducted to compare changes in their English writing ability reflected by their English writing scores changes between CG and TG in this study. All the English writing papers from English writing applied ability pre-test and English writing applied ability post-test were read by the same English writing teacher. Comparison of Means was adopted to compare the two groups of non-English-majored graduate students' average scores of their pre-test and post-test on the basis of samples. And the independent sample T-test was adopted to examine if there were significant differences between CG and TG of pre-tests and post-tests. Also the independent sample T-test was adopted to examine if 
there were significant differences between male and female graduate students in CG and TG. Interviews were conducted to collect responses from participates in TG in this study on FFI in the flipped classroom model in English writing. After the experiment of FFI in the flipped classroom model used in non-English-majored graduate students' English writing, interviews were held from 15:00 to 17:00 December 23, 2017 in a classroom to gain the responses from participants in TG on FFI in the flipped classroom model in English writing.

\section{Process of FFI in the Flipped Classroom in Non-English-Majored Graduates' English Writing}

Steps to Writing Well (tenth edition written by Jean Wyrick) published by Peking University Press as the textbook was used in teaching English writing for non-English-majored graduates in CG and TG. In the experiment, participants in the control group were instructed by the traditional grammar-translation English writing teaching and learning model (teachers explaining writing knowledge points and difficult sentences in the passages through grammar-translation method, then students listening to teachers' English writing instruction and handing in their completed English compositions to English writing instructor to correct the errors or mistakes in their English compositions). However, participants in the treatment group were instructed by FFI in the flipped classroom model in English writing. FFI in the flipped classroom model in English writing in this study was divided into three parts. The new teaching model: FFI in the flipped classroom model in English writing in the current study was divided into three parts: outside of the non-English-majored graduate students' English wiring class, in class of the non-English-majored graduate students' English wiring and outside of the non-English-majored graduate students' English wiring class. The first part, outside of the non-English-majored graduate students' English wiring class, was that participants in TG learned knowledge by watching the videos on FFI in the English reading and English wiring texts (FFI such as lexical, grammatical, and pragmalinguistic features applied in the article they were reading) made by the non-English-majored graduate students' English wiring instructor online or downloaded by the non-English-majored graduate students outside of a flipped classroom to complete the non-English-majored graduate students' English wiring tasks, self-tested tasks and reciting $50 \%$ of the content they read before their English wiring class and to make the summary of the texts they learned. The non-English-majored graduate students can communicate with their English writing instructor on their English writing course via the communication platform online QQ or We-Chat (a kind of online instant message service tool in China) by their computers or their smart phones if students want to ask the English writing instructor questions related to English writing. The second part, in the non-English-majored graduate students' English wiring class, was that the non-English-majored graduate students' English wiring instructor organized and guided students learning FFI in English writing through independent study, collaborative learning, group discussion, achievement exchange and reports. For example, 3-4 students can be organized as one group according to their wills to discuss and share their learning to solve FFI questions related to lexical, grammatical, and pragmalinguistic features or questions such as agreement of subject and predicate, vocabulary errors they met in their English academic writing or English compositions. Then the representative of every group reported his or her group's learning achievement on how to apply the form-focused instruction in their English writing. In class of a flipped classroom in teaching English writing, the non-English-majored graduate students' English writing instructor organized and guided FFI in the students' learning activities on how to apply FFI in their English writing also joined in students' discussion on FFI applied in the English writing to scaffold non-English-majored graduate students to focus their attentions to the correct forms and errors to forms avoided in their English writing. The third part, outside of FFI in the flipped classroom model in English writing, was that the non-English-majored graduate students needed write their FFI in English writing lesson summary about their learning in class, and their FFI in English writing lesson summary submitted online to their English writing instructor, at the same time, English compositions of participants in TG were handed to the English writing instructor to be read and be polished; after one day or several days, non-English-majored graduate students could read the comprehensive evaluation and feedback of FFI in their English writing from the non-English-majored graduate students' English writing instructor.

\section{Results}

The results of the experience: FFI in the flipped classroom model in non-English-majored graduate students' English writing in this study included three parts. The first part was English writing applied skills and ability tests' results of pre-tests and post-tests between CG and TG. The second part was whether there were significant differences between males and females, as CG with a traditional English writing teaching model compared to TG with FFI in the flipped classroom model in English writing. The last part was responses of interviews on FFI in the flipped classroom model in non-English-majored graduates' English writing. 


\subsection{Effects of FFI in the Flipped Classroom Model in English Writing on Non-English-Majored Graduates' English Writing Performance}

Table2 showed that non-English-majored graduate students' English writing performance from CG and TG before and after the experiment. The results from Table 1 showed non-English-majored graduates' English writing performance pre- tests' scores and non-English-majored graduates' English writing performance post-tests' scores between CG and TG taught by different English writing teaching methods. In the scores of pre-tests of English writing between the two groups $(\mathrm{CG}, \mathrm{TG})$, there was no significant difference $(\mathrm{t}=.212$, $\mathrm{P}=.833)$ between $\mathrm{CG}(\mathrm{M}=79.039, \mathrm{~S}=9.704)$ and $\mathrm{TG}(\mathrm{M}=78.745, \mathrm{~S}=9.169)$. However, after the experiment, non-English-majored graduates were trained by the different English writing instructions in their English writing performance post-tests' scores, a significant difference $(\mathrm{t}=-1.369, \mathrm{P}=.018)$ was found between the two groups: $\mathrm{CG}(\mathrm{M}=79.863, \mathrm{~S}=8.032)$ and $\mathrm{TG}(\mathrm{M}=81.784, \mathrm{~S}=9.523)$. After trained by traditional English writing method and trained by FFI in the flipped classroom model in English writing, all the 102 non-English-majored graduates in CG and TG, both two groups' English writing applied skills and ability mean scores were higher than their English writing applied skills and ability mean scores before the experiment. However, participants in TG trained by FFI in the flipped classroom model in English writing, their mean scores $(\mathrm{M}=81.784)$ were higher than that of participants in CG's mean scores (M=79.863).

Table 2. Results of non-English-majored graduates' English writing scores of pre-test and post-test

\begin{tabular}{lcccccc}
\hline \multicolumn{1}{r}{ Tests } & $\mathrm{CG}(\mathrm{N}=51)$ & \multicolumn{2}{c}{$\mathrm{TG}(\mathrm{N}=51)$} \\
Groups & $\mathrm{M}$ & $\mathrm{S}$ & $\mathrm{M}$ & $\mathrm{S}$ & $\mathrm{t}$ & \multicolumn{2}{l}{$\mathrm{P}$} \\
\hline Pre-test & 79.039 & 9.704 & 78.745 & 9.169 & .212 & .833 \\
Post-test & 79.863 & 8.032 & 81.784 & 9.523 & -1.369 & $.018^{*}$ \\
\hline
\end{tabular}

$\mathrm{M}$ stands for Mean; $\mathrm{S}$ stands for standard deviation; $* \mathrm{P}<.05 ; * * \mathrm{P}<.01$.

\subsection{Results of the T-test About Males and Females in CG and TG Taught by Different English Writing Approach}

Table 3 showed that significant differences were found between males and females in the two groups: CG and TG. Males $(\mathrm{P}=.04)$ suggested that a significant difference was found between $\mathrm{CG}$ and $\mathrm{TG}$ in their English writing applied skills and ability after trained by FFI in the flipped classroom model in English writing and females $(\mathrm{P}=.02)$ suggested that a significant difference was found between $\mathrm{CG}$ and $\mathrm{TG}$ in their English writing applied skills and ability after trained by FFI in the flipped classroom model in English writing.

Table 3. Results of the T-test about males and females in CG and TG taught by different English writing approach

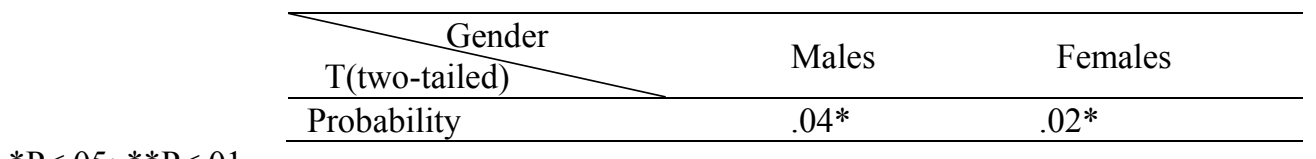

${ }^{*} \mathrm{P}<.05 ;{ }^{* *} \mathrm{P}<.01$.

\subsection{Results of Responses of Interviews From Non-English-Majored Graduates in TG on English Writing Teaching and Learning Through FFI in the Flipped Classroom Model}

After the experiment, December 23, 2017, all 51 participants in TG in this study were interviewed in one classroom to write down their responses towards the following interview questions: 1) Do you think your English writing skills and ability has been improved by the new writing teaching method of FFI in the flipped classroom model in English writing? 2) What are difficulties when you apply FFI in the flipped classroom model in your English writing? 3) Do you think all of you in TG are benefited by the new writing teaching method of FFI in the flipped classroom model in your English writing?

To question 1) Do you think your English writing skills and ability has been improved by the new writing teaching method of FFI in the flipped classroom model in English writing? Among 51 participants in TG, 49 participants told that they found their English writing ability was improved after they were trained by FFI in the flipped classroom in English writing. They paid more attention to the English writing tasks such as reciting the articles' content they read, so they knew how to choose correct words, correct verb tenses, correct numbers, 
correct word spellings and so on in their English writing. In the English writing class, they could focus the forms (such as verb tenses, numbers, word spellings) in their classmates' English compositions or English articles and they could focus on form from the English writing instructor on their own compositions outside of the English writing class. Their English writing skills and ability was improved by different practices FFI in the flipped classroom model in English writing. Only 2 participants in TG said that they did not find their English writing ability improved after they were trained by FFI in the flipped classroom in English writing.

To question 2) What are difficulties when you apply FFI in the flipped classroom model in your English writing? Among 51 participants in TG, 39 participants said that they could not express their ideas in English in their writing compositions or articles without enough vocabulary; 12 participants told that they paid all their attention to the correct grammatical application such as agreement of subject and predicate, irregular verbs, verb tenses and making correct English sentences in English writing, but the application of correct grammatical forms, making correct English sentences and other sentences manipulation in English writing for them were so difficult in English writing.

To question 3) Do you think all of you in TG are benefited by the new writing teaching method of FFI in the flipped classroom model in your English writing? Among 51 participants in TG, 49 participants told that they were benefited from FFI in the flipped classroom model in English writing; only 2 participants expressed the different opinion: they was not benefited from FFI in the flipped classroom model in English writing.

Table 4. Results of responses of interviews from non-English-majored graduates in TG taught by the new approach

\begin{tabular}{lcccc}
\hline Question & Acceptance & Percentage & Un-acceptance & Percentage \\
\hline 1 & 49 & 96.08 & 2 & 3.92 \\
2 & 39 & 76.47 & 12 & 33.53 \\
3 & 49 & 96.08 & 2 & 3.92 \\
\hline
\end{tabular}

\section{Discussion}

The authors in this study want to investigate the answers to the following three questions. One of the purposes in this study is to investigate if non-English-majored graduates' English writing applied skills and ability can be improved by FFI in the flipped classroom model. Improvement of participants' English writing applied skills and ability in TG shows the important role of FFI in the flipped classroom played for non-English-majored graduates' English writing teaching and learning.

According to the results in Table 2, we find that participants in this study trained by the different English writing instructions: the traditional grammar-translation English writing teaching method for CG and FFI in the flipped classroom model for TG. After trained in English writing classes, participants' English writing applied skills and ability scores in two groups (CG and TG) are both increased, that is to say, non-English-majored graduate students' English writing ability were both improved. However, scores of participants in TG are higher than that of participants in CG, which means that non-English-majored graduates' English writing applied skills and ability can be improved by FFI in the flipped classroom model. We think that FFI in the flipped classroom model in English writing encourages non-English-majored graduates to attract their attentions to forms through listening to English writing instructor's explanation, reciting the article they learned and discussion with their classmates on form in their English writing to increase their awareness of focusing on form and of inputting correct forms in their English writing then FFI applied into their English compositions, and during English writing class, they are organized or guided by their English writing instructor to share reading their English compositions written by themselves to discuss their questions, their focus on form in their English writing with their classmates in groups to get help from the classmates or the instructor, after class they can get their comprehensive English writing evaluation from their English writing instructor about their English compositions. We may find that FFI in the flipped classroom model in English writing agrees with the theory of Constructivism to encourage non-English-majored graduates to learn knowledge by themselves (according to the theory of Constructivism, knowledge is not taught but is learned by the learner himself through constructing the new knowledge on the basis of old knowledge, under certain settings). FFI in the flipped classroom model in English writing provides non-English-majored graduate students the environment (the English writing class) to share, discuss their application of FFI into their English compositions and get helps from their classmates or their instructor if they meet questions in their English writing, which agrees with the theory of Constructivism (with 
the help of others, such as the teachers or learning partners), and utilizes certain study resources (such as teaching PPT, online resources).

After trained by FFI in the flipped classroom model in English writing, most of male and female non-English-majored graduate students in TG successfully learn how to improve their English writing applied skills and ability by completing their writing tasks to apply FFI into their real English compositions. In English writing class, they discuss the form focused in their English compositions and questions on the form related to English writing with their group members or their instructor to provide help from their classmates or the instructor, so they show better in their English writing, compared with male and female non-English-majored graduates in CG. And there are significant differences between males and females in CG and TG. Male and female English-majored graduate students in TG could have the opportunity to discuss their questions or difficulties with their group members or the English writing instructor, so their group members or the English writing instructor help them solve their form-focused questions or difficulties they met during their English writing process, which would provide chances for non-English-majored graduate students in TG to improve their English writing applied skills and ability because of their English writing form-focused questions or difficulties solved.

Non-English-major graduates in TG generally holding positive responses for FFI in the flipped classroom model in English writing suggests that FFI in the flipped classroom model in English writing applied into regular non-English-majored graduate students English writing curriculum is a worthy try. FFI in the flipped classroom model in English writing is tentative method for non-English-majored graduates to learn how to write their compositions more correct in English. Results in this study agree with results in the researchers' studies (Gao, 2009; Li, 2013) in improving learners' language applied ability. Although 49 participants(96.08\%) in TG think their English writing applied skills and ability has been improved by FFI in the flipped classroom model in English writing, FFI in the flipped classroom model in English writing is not beneficial to all 51 participants in TG, and FFI in the flipped classroom model in English writing is difficult for participants in TG to be applied in their English writing due to their limitations such as vocabulary quantity, grammatical grasp level and so on, so the English writing instructor needs help non-English-majored graduate students solve their learning difficulties such as how to provide more chances for students to apply form-focused knowledge in their English writing.

\subsection{Limitations and Suggestions for Further Research}

Though the present study has investigated a survey of form-focused instruction among the 51non-English-majored graduate students in English writing teaching and learning, there are still some limitations in the study. Firstly, the time limitation (only 105days) in this study is obvious and the participants in the study consisted of only 102 non-English-majored graduate students from one university are needed to be broadened in further research. Secondly, the instruments used in this study to investigate the non-English-majored graduate students' English writing instruction involve pre-tests and post- tests to measure non-English-majored graduate students' English writing skills and ability and interviews to gain responses from participants in TG on FFI in their English writing. The study would be much better, if it were combined with other instruments such as verbal report, observation, and video record. More instruments should be used in investigating in the further research. Finally, participants in this study are the non-English-majored graduate students in only one university. The study will be better if more participants from other universities can be participated in the experiment.

Despite of the restraints of the study, we hope that it can offer some guidelines for further research of FFI on non-English-majored graduate students' English writing.

\section{Conclusion}

Taken as a whole, these results in this study would indicate that FFI in the flipped classroom model in English writing can effectively be integrated into the language learning curriculum and plays a positive role in improving learners' English writing applied skills and ability. The results showed that 1) compared with a traditional English writing approach for CG, FFI in the flipped classroom model in teaching English writing for TG did a better job in enhancing students' English writing skills and ability; 2) there were significant differences between males in CG and TG, and females in CG and TG;3) participates in TG generally held positive responses towards FFI in the flipped classroom model in English writing. FFI in the flipped classroom model on non-English-majored graduates' English writing will be a good try in English language teaching and learning. 


\section{References}

Aljumah, F.H. (2012). Saudi learner perceptions and attitudes towards the use of blogs in teaching English writing course for EFL Majors at Qassim University. English Language Teaching, 5(1), 100. https://doi.org/10.5539/elt.v5n1p100

Al-Kathiri, F. (2015). Beyond the classroom walls: Edmodo in Saudi secondary school EFL instruction, attitudes and challenges. English Language Teaching, 8(1), 189-204. https://doi.org/10.5539/elt.v8n1p189

Amber, G.R. (2009). Teaching Grammar to Adult English Language Learners: Focus on Form. Center for Applied Linguistics, 4, 1-4.

Beniko, M., \& Krashen, S. (2004). Is form-focused vocabulary instruction worthwhile? A Journal of Language Teaching and Research, 35(2), 179-185.

Bergmann, J., \& Sams, A. (2012). Flip Your Classroom: Reach Every Student in Every Class Every Day. Teaching Theology \& Religion, 17(1), 82-83. https://doi.org/10.1111/teth.12165

Educause Learning Initiativ. (2012). 7 things you should know about flipped classrooms. Retrieved from http://net.educause.edu/ir/library/pdf/ELI7081.pdf

Ellis, R. (2016). Anniversary article Focus on form: A critical review. Language Teaching Research, 20(3) 405-428. https://doi.org/10.1177/1362168816628627

Gao, S.X. (2009). Focus on Form in College English Teaching. English Language Teaching, 2(2), 46-48. https://doi.org/10.5539/elt.v2n2p46

Huang, R.H. (2009). Form-Focused Instruction and Planned Lexical Instruction. Foreign Language World, 3, 33-39.

Huelskamp, D. (2015). Flipping the Collegiate Science Classroom: A Review of the Research. Global Education Journal, 2015(1).

Kang, N. (2015). The comparison between regular and flipped classrooms for EFL Korean adult learners. Multimedia-Assisted Language Learning, 18(3), 41-72. Retrieved from http://journal.kamall.or.kr/wp-content/upload/2015/10/kang-18-3-02.pdf

Li, Q. (2013). The effects of post-task focus on form on Chinese EFL learners' oral performance. Foreign Language Teaching and Research, 45(2), 214-226.

Long, M. (1988). Instructed interlanguage development. In L. Beebe (Ed.), Issues in second language acquisition: Multiple perspectives (pp.115-141). Rowley, MA: Newbury House.

Long, M. (1991). Focus on form: A design feature in language teaching methodology. In K. de Bot, R. Ginsberg, \& C. Kramsch (Eds.), Foreign language research in cross-cultural perspective. Amsterdam: John Benjamins. https://doi.org/10.1075/sibil.2.07lon

Wang B.L. (2016). An Exploration of Focus on Form in Post-task Peer Interaction at a Chinese University EFL Classroom. Foreign Languages and Their Teaching, 1, 41-49.

\section{Copyrights}

Copyright for this article is retained by the author(s), with first publication rights granted to the journal.

This is an open-access article distributed under the terms and conditions of the Creative Commons Attribution license (http://creativecommons.org/licenses/by/4.0/). 